\title{
INTERNALISASI NILAI-NILAI SPIRITUAL DAN SOSIAL SANTRI DALAM SHALAT BERJAMAAH (PENELITIAN DI PONDOK PESANTREN LA TANSA ISLAMIC BOARDING SCHOOL PARAKANSANTRI, LEBAKGEDONG, LEBAK-BANTEN)
}

\author{
M. Syara Nurhakim \\ STAI Syekh Mansur, Pandeglang \\ Email : syaranurhakim@gmail.com
}

\begin{abstract}
This research is motivated by the lack of application of spiritual and social values which are considered important in the implementation of congregational prayers in order to achieve the goal of perfect worship, both physically and mentally. The purpose of this study is to determine the meaning of the spiritual and social values of students in congregational prayers at the La Tansa Islamic Boarding School. To find out the process of applying the spiritual and social values of students in congregational prayers, as well as their implications for the lives of students at the La Tansa Islamic Boarding School. The research method used is a qualitative research method. The data collection tools used observational analysis, interviews, and documentation studies. The results of this study indicate that spiritual values are values contained in the human soul, which in the human soul has a spirit. The essence of spiritual value is the spirit. Everyone must have a spirit and that spirit is in their own soul. The only one who knows about the spirit is Allah while the creatures do not. While social values are values held by society, regarding what is considered good and what is considered bad by society.
\end{abstract}

Keywords: Social Values, Spiritual Values, Islamic Boarding School

\begin{abstract}
Abstrak
Penelitian ini dilatar belakangi dengan kurangnya penerapan nilai-nilai spiritual dan sosial yang dipandang penting dalam pelaksanaan shalat berjamaah guna mencapai tujuan ibadah yang sempurna, baik secara lahir maupun batin. Tujuan penelitian ini yaitu: untuk mengetahui makna nilai spritual dan sosial santri dalam shalat berjamaah di Pondok Pesantren La Tansa. Untuk mengetahui proses penerapan nilai-nilai spiritual dan sosial santri dalam shalat berjamaah, serta implikasinya terhadap kehidupan santri di Pondok Pesantren La Tansa. Metode penelitian yang dipakai adalah metode penelitian kualitatif. Alat pengumpulan data menggunakan analisis observasi,wawancara, dan studi dokumentasi. Hasil penelitian ini menunjukan bahwa nilai spiritual merupakan nilai yang terdapat dalam jiwa manusia, yang mana di dalam jiwa manusia itu memiliki ruh. Inti dari nilai spiritual adalah ruh. Setiap orang pasti memiliki ruh dan ruh itu terdapat dalam jiwa masing-masing. Yang tahu soal ruh itu hanya Allah sedangkan makhluknya tidak. Sedangkan nilai sosial merupakan nilai yang dianut oleh masyarakat, mengenai apa yang dianggap baik dan apa yang dianggap buruk oleh masyarakat.
\end{abstract}

Kata kunci: Nilai Sosial, Nilai Spiritual, Pesantren 


\section{Pendahuluan}

"Pendidikan adalah usaha sadar dan terencana untuk menyiapkan peserta didik melalui kegiatan bimbingan, pengajaran, dan atau latihan bagi peranannya di masa yang akan datang. Sedangkan pendidikan nasional adalah pendidikan yang berakar pada kebudayaan bangsa Indonesia dan yang berdasarkan pada Pancasila dan Undang-Undang Dasar" (Sulaiman, 2002). Singkatnya, pendidikan adalah usaha sadar dan sistematis untuk mencapai taraf hidup atau kemajuan yang lebih baik. Tekanan dalam hal ini adalah sadar dan sistematis, kita harus yakin bahwa dengan pendidikan bisa merubah taraf hidup serta pola pikir kita dan kemajuan bangsa.

Indonesia merupakan negara mayoritas muslim, salah satu cirinya adalah dengan adanya Pondok Pesantren. Keberadaan Pondok Pesantren sebagai lembaga pendidikan yang di dalamnya mengkaji ilmu agama Islam, telah diakui turut serta mencerdaskan kehidupan bangsa dan merupakan kekayaan tersendiri bagi perkembangan pendidikan di Indonesia. Menurut Nurcholis Madjid, "bila dilihat dari segi historis pesantren tidak hanya identik dengan makna keIslaman, tapi juga mengandung makna keaslian Indonesia (indigenous)" (Madjid, 1997: 87). Pesantren muncul dan berkembang dari pengalaman sosiologis masyarakat lingkungannya. Dengan kata lain pesantren mempunyai keterkaitan serta yang tidak terpisahkan dengan komunitas lingkungannya.

Dalam dunia pesantren, santri banyak diajari dengan berbagai ilmu agama seperti : fiqih, faroid, nahwwu, sorof dan lain sebagainya. Tidak hanya itu santri juga diajari untuk berdisiplin dalam segala hal, baik dalam hal belajar, aktifitas olahraga dan dalam kegiatan beribadah, seperti penekan disiplin dalam salat berjamaah, dimana santri dituntut untuk mengikuti salat berjamaah dalam 5 waktu. Eman Sulaiman mengungkapkan bahwa "salat merupakan ibadah paripurna yang mamadukan olah pikir, olah gerak, dan olah rasa (sensibilitas), ketiganya terpadu secara harmonis. Salat pun merupakan kontemplasi dan riyadah (latihan) yang terintegrasi sempurna, saling melengkapi dari dimensi perilaku atau lisan (al bayan), respon motorik, rasionalitas (menempatkan diri secara proporsional ), dan kepekaan terhadap jati diri, kepekaan dan kehalusan untuk merasakan cinta dan kasih sayang Allah Swt" (Sulaiman, 2002: 7-8).

Pondok Pesantren La Tansa merupakan salah satu Pesantren Modern yang menerapkan disiplin mengenai salat berjamaah. Seluruh santri diwajibkan untuk mengikuti salat berjamaah dalam 5 waktu, jika tidak mengikuti salat berjamaah maka santri akan mendapatkan hukuman atau yang disebut dengan $i$ 'qob. Namun fenomena yang terjadi di Pondok Pesantren La Tansa kebanyakan dari santri belum memahami makna dari nilai salat berjamaah itu sendiri, padahal sudah jelas di dalam Al-Qur' an katakan bahwa "Salat itu mencegah dari perbuatan keji dan mungkar". Sebagai makhluk sosial, tentunya manusia tidak bisa hidup sendirian. Secara alamiah, manusia mempunyai panggilan untuk selalu hidup bersama orang lain dan berinteraksi dengan mereka. Interaksi sosial yang manusia butuhkan tentu tidak hanya sekadar interaksi biasa, tetapi interaksi sosial yang berkualitas yang dibangun atas dasar kasih sayang, ketulusan, dan harmoni (Rahman, 2013: 2). Akan tetapi yang terjadi pada santri di Pondok Pesantren La Tansa masih banyak dari santri yang hidup secara individualisme, meskipun mereka hidup dalam satu ruang lingkup tetapi mereka tidak mengenal semua.

Kemudian setelah mereka lulus dan menjadi alumni, kebanyakan dari mereka hidup masing-masing artinya jarang sekali mereka melakukan kumpul 
bersama. Padahal mereka sudah difasilitasi oleh komunitas alumni, yang mana bertujuan untuk mempersatukan alumni pesantren serta menampung gagasan dari yang mereka miliki. Akan tetapi kebanyakan dari mereka jarang ikut bergabung dengan komunitas tersebut. Pondok Pesantren La Tansa adalah satuan pendidikan non formal yang menyelenggarakan pendidikan pada jenjang pendidikan menengah pertama, menengah atas, dan menengah kejuruan. Pondok Pesantren La Tansa beralamat di Parakansantri, Lebakgedong, Lebak-Banten. Pesantren ini memadukan antara kurikulum pendidikan nasional dan kurikulum pesantren yang dibuat langsung oleh pesantren dengan memadukan pelajaran umum. Di pesantren ini sering ditemukan santri yang bolos, merokok dan lain sebagainya di lingkungan pesantren. Tak jarang dari santri banyak yang tidak melakukan salat berjamaah atau tidak melaksanakan salat sama sekali, namun pihak pesantren selalu berupaya menangani hal tersebut karena sadar akan fungsi pesantren sebagai lembaga yang menanamkan nilai-nilai keislaman. Pihak pesantren menyadari jika tidak di didik dari remaja maka akan sulit untuk menerapkan nilainilai spiritual ataupun sosial kepada santri sebagai bekal mereka untuk masa yang akan datang. Dalam hal ini semua guru memiliki peran penting untuk mendidik santri dalam hal disiplin, akan tetapi dalam hal ini lebih ditekankan kepada bagian peribadatan atau ubudiyah. Karena dalam hal ini ditekankan untuk mengingatkan santri dalam salat serta memberikan siraman rohani dan membimbing sesuai norma-norma agama kepada para santri.

\section{Kajian Teori}

Salat adalah ibadah yang tidak akan pernah hilang dari napas kehidupan seorang Muslim. Jadi, salat merupakan perbuatan yang terus menerus dilakukan seorang Muslim selama dia hidup. Sulaiman Rasjid mengatakan bahwa, "makna salat menurut bahasa Arab ialah "doa", tetapi yang dimaksud disini ialah ibadat yang tersusun dari beberapa perkataan dan perbuatan yang dimulai dengan takbir, dan disudahi dengan salam, dan memenuhi beberapa syarat yang ditentukan" (Rasjid, 2002: 53). Salat merupakan rukun Islam yang ke lima yang merupakan kewajiban bagi umat Muslim, dalam sehari semalam umat Muslim melakukan salat dalam 5 waktu.

Aziz Fahrurrozi mengatakan, "salat sebagai tiang agama yang mengisyaratkan adanya bangunan Islam yang kekokohan bangunan itu sangat tergantung pada tiang yang menyanggahnya. Ketika tiangnya kuat, maka bangunan pun akan kuat, dan jika tiangnya rapuh, maka bangunannya pun rapuh" (Fahrurrozi, 2010: 58).

Salat di ibaratkan seperti tiangnya agama, agar tiang tersebut kuat maka kita harus memperkuat tiang tersebut dengan dasar pondasi. Pondasi yang di bangun di sini merupakan bentuk keimanan kita yang dilafalkan melalui dua kalimat syahadat. Dalam hal ini tidak di lihat dari kuantitas atau banyaknya orang melaksanakan salat, akan tetapi dilihat dari kualitas salat seseorang sejauhmna dia mampu memahami syarat dan rukun salat sehingga orang tersebut bisa mencapai tingkat kekhusyuan dalam salat. Ketika sesorang tidak melaksanakan salat atau meninggalkan salat, maka dia sama saja telah merubuhkan agamanya. Sebagaimana sabda Rasulullah Saw :

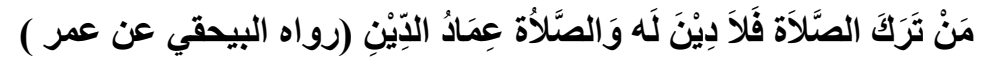

"Siapa saja yang meninggalkan salat maka ia telah merubuhkan agamanya, salat adalah tiang agama” (HR. Baihaqi dari Umar) 
Salat yang dilakukan oleh dua atau tiga orang disebut dengan salat berjamaah, salat berjamaah bagi kaum laki-laki hukumnya fardu kifayah. Syekh Nawawi mengatakan bahwa, "salat berjamaah bagi kaum laki-laki merdeka yang bermukim (menetap) di kampungnya, tidak sedang berpergian jauh, telah balig, dan tidak berhalangan (misalnya: sakit, hujan lebat), adalah fardu kifayah" (Nawawi, t.t: 59). Rasulullah Saw bersabda yang artinya:

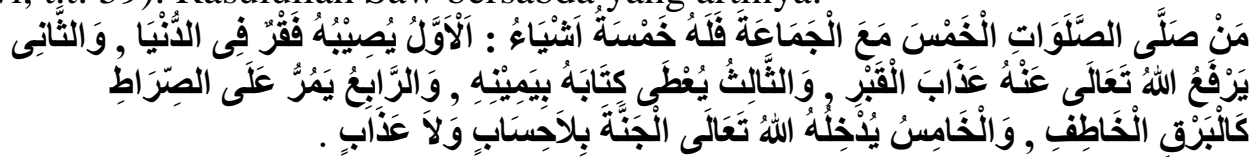

"Barang siapa melaksanakan salat lima waktu secara berjamaah, dia akan memperoleh lima perkara: (Pertama) Dia tidak akan ditimpa kemiskinan di dunia. (Kedua) Allah Taala menghapuskan siksa kubur dari dirinya, (Ketiga) Dia akan diberi kitab catatan amalnya dari sebelah kanannya, (Keempat) Dia akan melintasi Sirat (titian diatas neraka) laksana kilat yang menyambar, (Kelima) Allah Taala memasukkannya ke dalam surga tanpa dihisap dan diazab”. (Mashaabih)

Setiap orang mempunyai kebutuhan fundamental sesuai dengan fitrahnya yang memiliki jasmani dan rohani, dan apabila dikaitkan dengan berbagai ragam hubungan manusia dalam kehidupannya, di setiap hubungan tersebut ada hubungan antara manusia dengan Tuhan, manusia dengan alam, manusia dengan manusia lain atau masyarakat, dan manusia dengan dirinya sendiri. Untuk memenuhi kebutuhan rohaninya manusia melaksanakan nilai spiritual dalam kehidupannya.

Menurut Ary Ginanjar, "nilai spiritual memiliki hubungan dengan sesuatu yang dianggap mempunyai kekuatan sakral suci dan agung. Karena itu termasuk nilai kerohanian, yang terletak dalam hati (bukan arti fisik), hati batiniyah mengatur psikis. Hati adalah hakekat spiritual batiniah, inspirasi, kreativitas dan belas kasih. Mata dan telinga hati merasakan lebih dalam realitas-realitas batiniah yang tersembunyi di balik dunia material yang kompleks. Itulah pengetahuan spiritual. Pemahaman spiritual adalah cahaya Tuhan ke dalam hati, bagaikan lampu yang membantu kita untuk melihat" (Ginanjar, 2009: 141).

Nilai spiritual merupakan nilai yang terdapat dalam jiwa manusia, yang mana di dalam jiwa manusia itu memiliki roh. Roh dikenal dalam berbagai bahasa : sprit (Ingg), Spirit (Romawi), dan Ruh (Arab). Menurut Ibnu Sina, "roh adalah kesempurnaan awal jisim manusia yang tinggi yang memiliki kehidupan dengan daya. Sedang bagi al-Farabi, roh berasalah dari alam perintah (amr) yang mempunya sifat berbeda dengan jasad. Hal itu dikarenakan ia dari Allah, kendatipun ia tidak sama dengan zat-Nya" (Lajnah Pentashihan Mushaf AlQur'an, 2014: 38-39).

Ajaran Islam tidak hanya bermuatan teori-teori (betapapun penuh dengan teori) melainkan juga bermuatan praktik atas teori yang dibicarakannya. Pernyataan Islam sebagai amal tidak boleh dipahami bahwa landasan teori menjadi tidak perlu. Akan tetapi, harus dipahami bahwa keunggulan seorang muslim terletak apada amalnya atau karyanya (ahsanukum amalan). Kata amal (a$m-i-l-a)$ tampaknya dibedakan oleh Al-Qur'an dengan kata $(f-a-a-l-a)$ yang berarti perilaku atau perbuatan. Kata amila lebih punya arti luas, yaitu mencakup 
perbuatan, ucapan, dan pernyataan tulisan bahkan niatnya hati. Jadi, fa 'ala lebih bersifat lahiriyah, apabila beramal sama dengan berkarya, maka bentuknya dan jenisnya bermacam-macam. Ada karya seni, karya tulis, ada karya lukis dan lainlain. Maka cocok sekali bila kata beriman (pengakuan atas kebenaran) digandengkan dengan perintah berkarya (beramal) (Fahrurrozi, 2010: 111).

Salat berjamaah akan berpengaruh terhadap nilai sosial seseorang yang salat selama mereka berjamaah. Pengaruh inilah yang akan mengantarkan kepada perubahan ke arah yang lebih baik dengan ruh amar ma'ruf nahi mungkar yang merupakan ruh salat. Untuk itu marilah kita senantiasa menjaga kualitas salat berjamaah, agar kita senantiasa saling bersatu dan saling menganal antara satu dengan yang lainnya.

\section{Metode Penelitian}

Jenis penelitian ini tergolong penelitian lapangan (field research) apabila dilihat dari tempat penelitian dilakukan. Penelitian lapangan (field research), yaitu "penelitian dengan menggunakan informasi yang diperoleh dari sasaran penelitian yang selanjutnya disebut informan atau responden melalui instrumen pengumpulan data seperti angket, wawancara, observasi dan dokumentasi" (Nata, 2000: 125). Sedangkan menurut Sugiono (Sugiono, 2009: 205), "penelitian kualitatif sering disebut metode penelitian naturalistik karena penelitiannya dilakukan pada kondisi yang alamiah (natural setting) disebut juga sebagai metode etnographi, karena pada awalnya metode ini lebih banyak digunakan untuk penelitian bidang antropologi budaya disebut sebagai metode kualitatif, karena data yang terkumpul dan analisisnya lebih bersifat kualitatif'. Adapun tipe penelitian ini, jika dilihat berdasarkan tujuan merupakan penelitian deskriptif. Penelitian deskriptif merupakan penelitian yang mendeskripsikan atau menggambarkan fenomena-fenomena yang ada, baik fenomena yang bersifat alamiah ataupun rekayasa manusia. Penelitian yang menggunakan metode ini juga bertujuan untuk memecahkan permasalahan pada masa sekarang, di antaranya adanya penyelidikan dengan penuturan, analisis dan klasifikasi (Syaodih, 2005: 72).

\section{Hasil Penelitian}

\section{Latar Alamiah Pondok Pesantren La-Tansa}

Pondok Pesantren "La Tansa" berdiri di sebuah lembah seluas \pm 13 ha yang sekelilingnya dialiri sungai Ciberang dan dikelilingi oleh gunung-gunung dan bukit yang menghijau. Keadaan seperti ini membuat Pondok Pesantren La Tansa terhindar dari polusi udara bahkan polusi budaya dan pergaulan amoral, merupakan tempat tafaqquh fiddien yang nyaman dan rekreatif.

Lembaga ini dikelola oleh Yayasan La Tansa Mashiro yang didirikan oleh Drs. KH. Ahmad Rifa'i Arief (Alm) dengan Akta Notaris No. 4 Tanggal 9 Januari 1991 dan Akta perubahan No. 44 Tanggal 20 April 1998, beralamat di Parakansantri, Cipanas, Lebak, Banten. Lahirnya Pondok Pesantren La Tansa didasarkan atas kesadaran untuk membangun sumber daya manusia yang beriman dan bertaqwa, berwawasan luas, berilmu, berakhlakul-karimah (mukminin, muttaqien dan rosikhina fil'ilmi) kelak menjadi generasi penerus bangsa, negara dan agama dalam pelbagai sektor kehidupan. 
Untuk mencapai cita-cita luhur di atas, Pondok Pesantren La Tansa menetapkan misi yang menjadi semangat dan jiwa dalam setiap gerak dan aktifitas, yaitu :

1. Mempersiapkan kader-kader muslim masa depan yang menguasai iptek, memiliki daya juang tinggi, mampu berkreasi secara inovatif, aktif dan dinamis di atas landasan iman dan taqwa yang kuat.

2. Mengombinasikan kurikulum pondok modern dengan kurikulum pendidikan nasional dalam rangka menghilangkan kesan dikotomi antara ilmu pengetahuan umum dan agama.

3. Memperluas medan juang dan dakwah santri meliputi seluruh aspek kehidupan dengan bekal iman sebagai landasan keyakinan, pandangan dan sikap hidup yang hak, ilmu dan keterampilan seni dan budaya.

4. Meningkatkan kemampuan profesionalisme dan pengetahuan tenaga kependidikan sesuai dengan kebutuhan dunia pendidikan dan tuntutan dinamika kehidupan masyarakat.

Selanjutnya, penjabaran misi itu diterjemahkan dalam sebuah sistem pendidikan dan pengajaran formal dan non formal disertai dengan aktifitas penunjang yang dapat membantu meningkatkan kualitas pendidikan dan pengajaran, sebagai upaya untuk melahirkan output pendidikan yang memiliki medan juang dan dakwah yang luas, kreatifitas seni, dan kesiapan mental, spiritual, serta intelektual untuk terjun ke tengah - tengah masyarakat dalam berbagai bidang dan profesi, dalam konteks memenuhi kebutuhan masyarakat luas yang heterogen. Salah satu dari penunjang itu adalah keberadaan Marching Band yang merupakan kegiatan ekstrakurikuler yang diformat untuk dapat mendukung proses pendidikan dan pengajaran di Pondok Pesantren La Tansa.

Pondok Pesantren La Tansa memiliki beberapa fasilitas penunjang bagi santri, salah satunya sarana ibadah berupa masjid yang memiliki dua lantai dan masjid tersebut diberi nama masjid jami "Mas'adul Husein". Tidak hanya itu, pesantren juga menyediakan asrama baik asrama putra maupun asrama putri. Asrama putra terdiri dari: gedung Ibnu Rusdy 2 lantai terdiri atas 14 lokal, gedung Ibnu Miskawaih 2 lantai terdiri atas 12 lokal, dan gedung Rifa'i 2 lantai terdiri atas 8 lokal. Untuk asrama putri terdiri dari: gedung Khadijah 2 lantai terdiri atas 12 lokal, gedung Hafshah 2 lantai terdiri atas 12 lokal, gedung Habibah 2 lantai terdiri atas 12 lokal, gedung Aisyah 2 lantai terdiri atas 12 lokal, gedung Halimatus Sa'diyah 2 lantai terdiri atas 24 lokal, gedung Saudah 2 lantai terdiri atas 12 lokal, dan gedung Mastufah 2 lantai terdiri atas 12 lokal. Tidak hanya asrama bagi santri, Pondok Pesantren La Tansa menyediakan perumahan bagi para ustadz yang tersebar di sekitar asrama putra dan putri.

Sejak awal didirikan Pondok Pesantren La Tansa oleh Drs. KH. Ahmad Rifa'i Arief (Alm) dengan jumlah santri 50 orang, yang merupakan santri pindahan dari Pondok Pesantren Daar El-Qolam Gintung Jayanti. Kemudian setelah lebih dari satu tahun jumlah santri bertambah semakin banyak. Setelah menyelesaikan program study, ada di antara para santri yang mengabdikan dirinya untuk menjadi pendidik di Pondok Pesantren La Tansa (Wawancara dengan AlUstadz Tamrin Hafidz, 02 Februari).

\section{Pelaksanaan Salat Berjamaah di Pondok Pesantren La Tansa}


Adapun waktu pelaksanaan salat berjamaah di Pondok Pesantren La Tansa sebagai berikut:

1. Waktu salat dzuhur dilaksanakan pada pukul $12.30 \mathrm{~s} / \mathrm{d} 13.00$ tepatnya setelah para santri selesai melaksanakan kbm pada jam ke-6

2. Waktu salat ashar dilaksanakan pada pukul $15.15 \mathrm{~s} / \mathrm{d} 16.00$ tepatnya setelah setelah santri selesai melaksanakan kbm pada jam ke-7

3. Waktu salat magrib dilaksanakan pada pukul $18.00 \mathrm{~s} / \mathrm{d} 18.45$ akan tetapi santri di wajibkan berada di masjid pada pukul 17. 35

4. Waktu salat isya dilaksanakan pada pukul $19.30 \mathrm{~s} / \mathrm{d}$ tepatnya setelah santri melaksanakan halaqoh

5. Waktu salat subuh dilaksanakan pada pukul $04.30 \mathrm{~s} / \mathrm{d} 05.15$ akan tetapi santri di wajibkan berada di masjid pukul 04.15

Bagi santri yang ingin melaksanakan salat sunah seperti salat dhuha, tahajud atau witir tidak dihukumi wajib untuk melaksanakan di masjid. Santri di perbolehkan melaksanakan salat tersebut di asrama masing-masing, tetapi kebanyakan dari santri yang melakukan salat dhuha di masjid pada pukul 08.30 tepatnya pada waktu istirahat pertama.

Salah satu salat sunah yang wajib untuk dilaksanakan yaitu salat sunah rawatib (qobliyah ba'diyah), kegiatan ini bertujuan untuk melatih santri agar terbiasa melakukan salat sunah yang di mulai dari salat sunah rawatib. Dengan harapan santri terbiasa melaksanakan salat sunah rawatib tidak hanya di dalam pondok, bahkan ketika sudah berada di luar pondok (Wawancara dengan KH. Adrian Mafatihullah Karim, 04 Februari 2017).

Dalam penelitian ini, peneliti berusaha untuk melihat sejauh mana penerapan nilai-nilai spiritual dan sosial santri dalam salat berjamaah. Berdasarkan hasil wawancara dengan Ustad Syihabudin (Wawancara dengan AlUstad H. Syihabudin Syukur, 06 Februari 2017) menunjukan bahwa masih kurangnya kesadaran santri dalam melaksanakan disiplin yang telah di tentukan oleh pondok pesantren. Hal ini terbukti dari masih banyaknya santri yang di hukum akibat tidak melaksanakan salat berjamaah sehingga masih perlu diingatkan oleh mudabbir. Padahal Nabi sudah menjelaskan dalam hadistnya bahwa pahala salat berjamaah adalah 27 derajat di banding salat sendiri. Di sadari atau tidak masih perlunya dilakukan bimbingan kepada para santri untuk meyakinkan bahwa salat berjamaah itu penting dilaksanakan, sehingga santri bisa terbiasa melaksanakan salat berjamaah dengan kesadaran sendiri tanpa adanya paksaan dari mudabir ataupun asatidz.

\section{Makna nilai spiritual dan sosial santri dalam salat berjamaah}

Secara umum, salat terdiri dari dua bagian yaitu bagian gerakan $\left(a f^{\prime} a l\right)$ dan bagian ucapan atau bacaan (aqwal). Pertama, berupa gerakan-gerakan yang di mulai dari takbiratul ikhram (mengangkat kedua tangan) hingga salam (menoleh ke kanan dan ke kiri). Kedua, berupa bacaan-bacaan baik yang berupa hukumnya wajib maupun sunnah. Kedua bagian ini sama-sama memiliki makna-makna sosiolgisnya, yang berpengaruh besar bagi kehidupan seseorang dalam menjalani hidup sehari-hari (Wawancara dengan Al-Ustad H. Syihabudin Syukur, 06 Februari 2017).

Jika seseorang melaksanakan salat dengan benar, baik dari segi bacaan ataupun gerakan maka dia akan mendapatkan banyak nilai yang terkandung dalam 
salat itu sendiri seperti nilai spiritual dan sosial. Takbiratul ikhram merupakan lambang penyerahan diri secara total kepada Allah Swt, Islam sendiri adalah agama kepasrahan penyerahan diri kepada Allah. Tetapi pasrah bukan berarti meniadakan usaha. Seseorang tetap wajib berusaha, tetapi ia harus berdoa kepada Allah dan memasrahkan segala keputusan akhir kepada-Nya. Inilah merupakan keterkaitan doa, usaha, dan pasrah.

Hal tersebut menunjukan bahwa dalam salat mengandung nilai spiritual. Pasrah merupak bentuk nilai spiritual dalam salat, karena pasrah merupakan bentuk penyerahan diri secara totalitas kepada sang Khalik. Untuk menanamkan rasa kepasrahan tesubut, maka di perlukan adanya pengosongan fikiran atau fokus terhadap ibadah. Adapun yang terjadi di Pondok Pesantren La-Tansa, masih ada sebagian santri yang masih belum mengerti sepenuhnya mengenai rukun dan syarat salat yang sebeneranya. Hal ini menyebabkan ketika santri melaksanakan salat baik secara berjamaah ataupun sendiri terkesan masih masih kurang benar, ini bisa dilihat dari cara gerakan salat, bacaan salat, serta dzikir dalam salat. Ini menunjukan belum tertanamnya nilai spiritual santri dalam melaksanakan salat.

Padahal salat merupakan suatu ibadah yang berhubungan langsung dengan Allah (hablun minallah), salat merupakan asupan rohani atau hati bagi manusia. Yang di maksud di sini adalah makrifat Tuhan dan rahasia ruhani yang masuk ke dalam relung hati. Asupan hati ini akan mendorong munculnya sifat-sifat dan ahwal (keadaan) terpuji (al-Iskandari, 2013: 16). Ada yang membuahkan karisma, ada yang mendorong kelembutan, dan ada pula yang memupuk kebenaran. Untuk menanamkan nilai spiritual santri dalam salat berjamaah tentunya membutuhkan sosok seorang figur guru agar bisa di contoh. Ketika guru sering mencontohkan hal-hal yang baik terhadap muridnya, tentu saja ia akan memiliki nilai lebih di hadapan muridnya. Hal ini tentu akan menambah nilai lebih bagi sang guru, tidak hanya itu ia akan menjadi panutan bagi muridnya baik dalam sgi spriritual ataupun sosialnya.

Akan tetapi yang terjadi di pondok pesantren la-tansa, tidak semua guru bisa mencontohkan hal yang baik terhadap muridnya terutama dalam melaksanakan shalat berjamaah. Ketika tiba waktu salat kebanyakan dari guruguru beristirahat di kediamannya masing-masing, sementara muridnya dibiarkan begitu saja ke masjid untuk melaksanakan salat berjamaah meskipun mereka sudah ada yang mengatur untuk salat berjamaah yang di sebut dengan mudabbir. Meskipun demikian peran guru sangat dibutuhkan untuk senantiasa menanamkan suri tauladan terhadap muridnya dan untuk senantiasa menamkan nilai-nilai spiritual dalam beribadah sesuai dengan anjuran pimpinan pesanten yaitu: dipaksa, terpaksa, biasa, kemudian menjadi bisa. Nilai spiritual terkadang dalam jiwa manusia atau dalam ruhani, Ary Ginanjar menjelsakan bahwa nilai spiritual merupakan nilai suci yang terkandung dalam diri manusai itu sendiri. Untuk dapat menanamkan nilai tersebut tentunya butuh bimbingan serta arahan dari seseorang, dalam hal ini lebih ditekankan kepada guru, karena guru memiliki tanggung jawab untuk mendidik muridnya tidak hanya di kelas akan tetapi di luar kelas.

\section{Penerapan nilai spiritual dan sosial dalam salat berjamaah}

Penanaman nilai sosial dan spiritual dalam salat berjamaah bagi santri merupakan salah satu upaya meningkatkan kualitas terbaik dalam menata jiwa, rasa, pikiran dan perilaku untuk menjalankan kehidupan yang rukun, damai serta harmonis. Untuk mencapai tujuan tersebut diperlukan peran guru, dimana guru 
bertugas untuk mengarahkan dan membimbing para siswanya dalam menjalankan kehidupan sehari-hari sesuai dengan ketetapan Islam dan mengaplikasikan nilai spiritual dan sosial dari salat berjamaah.

Salah satu rumus ibadah adalah ikhlas, segala sesuatu yang kita lakukan termasuk ibadah jika tanpa didasari oleh rasa ikhlas maka tidak akan berpengaruh apa-apa baik dampak sosial ataupun spiritual.

Allah Swt berfirman dalam surat Al-Ankabut ayat 45:

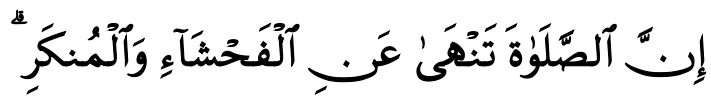

\section{"Salat itu mencegah dari perbuatan keji dan munkar"}

Salat tidak akan berdampak terhadap pencegahan keji dan munkar, manakala salat tersebut dilakukan dengan ikhlas. Sedangkan untuk menentukan seseorang itu ikhlas atau tidak dalam salatnya itu sangat sulit, akan tetapi minimal kita bisa melihat dari gerakan salat, serta raut muka orang yang sedang salat. Yang terjadi di pondok pesantren ini, kebanyakan dari santri belum memiliki rasa ikhlas untuk melaksanakan ibadah, jika saja rasa ikhlas itu sudah mereka miliki maka mereka tidak usah di paksa pun sudah sadar dengan sendirinya (Wawancara dengan Al-Ustad H. Syihabudin Syukur, tanggal 10 Februari 2017).

Ibnu Katsir menafsirkan QS. Al-Ankabut ayat 45, salat itu mengandung dua hikmah yaitu dapat menjadi pencegah diri dari perbuatan keji dan perbuatan munkar. Maksudnya dapat menjadi pengekang diri dari kebiasaan melakukan perbuatan tersebut dan mendorong pelakunya dapat menghindarinya. Di dalam sebuah hadtis melalui riwayat Imran dan Ibnu Abbas secara marfu disebutkan barang siapa yang salatnya masih belum dapat mencegah dirinya dari mengerjakan perbuatan keji dan munkar, maka tidak lain ia makin bertambah jauh dari Allah (Katsir: t.t, jil. 3: 414).

Salah satu cara yang dilakukan oleh pihak pondok pesantren agar membiasakan santri untuk salat berjamaah, yaitu dengan memberdayakan mudabbir yang di jalankan oleh kelas 6. Setiap kali datang waktu salat mereka langsung bertugas untuk mengingatkan santri untuk pergi ke masjid. Akan tetapi amat di sayangkan hal ini secara tidak langsung memaksa santri sehingga dalam dirinya tidak timbul rasa tidak ikhlas untuk melaksanakan salat berjamaah di masjid.

Ibnu Katsir menafsirkan QS. Al-Ankabut ayat 45, salat itu mengandung dua hikmah yaitu dapat menjadi pencegah diri dari perbuatan keji dan perbuatan munkar. Maksudnya dapat menjadi pengekang diri dari kebiasaan melakukan perbuatan tersebut dan mendorong pelakunya dapat menghindarinya. Di dalam sebuah hadtis melalui riwayat Imran dan Ibnu Abbas secara marfu disebutkan barang siapa yang salatnya masih belum dapat mencegah dirinya dari mengerjakan perbuatan keji dan munkar, maka tidak lain ia makin bertambah jauh dari Allah (Katsir: t.t, jil. 3: 414).

Salah satu cara yang dilakukan oleh pihak pondok pesantren agar membiasakan santri untuk salat berjamaah, yaitu dengan memberdayakan mudabbir yang di jalankan oleh kelas 6. Setiap kali datang waktu salat mereka langsung bertugas untuk mengingatkan santri untuk pergi ke masjid. Akan tetapi amat di sayangkan hal ini secara tidak langsung memaksa santri sehingga dalam 
dirinya tidak timbul rasa tidak ikhlas untuk melaksanakan salat berjamaah di masjid.

\section{Kesimpulan}

Berdasarkan hasil penelitian yang telah dipaparkan dalam tesis ini, maka peneliti menyimpulkan: Nilai spiritual merupakan nilai yang terdapat dalam jiwa manusia, yang mana di dalam jiwa manusia itu memiliki roh. Nilai spiritual memiliki hubungan dengan sesuatu yang dianggap mempunyai kekuatan sakral suci dan agung. Karena itu termasuk nilai kerohanian, yang terletak dalam hati (bukan arti fisik), hati batiniyah mengatur psikis. Nilai spiritual ibarat obor atau lampu yang menerangi setiap hati manusia, untuk dapat menyalakan obor tersebut manusia harus mengisi hati dengan rutinitas yang berhubungan dengan nilai ruhani atau spiritual. Sedangkan nilai sosial adalah nilai yang dianut oleh suatu masyarakat, mengenai apa yang dianggap baik dan apa yang dianggap buruk oleh masyarakat. Nilai sosial merupakan sesuatu pandangan yang dianggap baik dan benar oleh suatu lingkungan masyarakat yang kemudian menjadi pedoman sebagi suatu contoh perilaku yang baik dan diharapkan oleh warga masyarakat. Nilai sosial dan spiritual akan berpengaruh terhadap shalat berjamaah, seperti dalam penerapannya jika shalat nilai spiritual memiliki hubungan langsung sedangkan nilai sosial memiliki hubungan langsung dengan makhluk. Penanaman nilai sosial dan spiritual dalam shalat berjamaah bagi santri merupakan salah satu upaya meningkatkan kualitas terbaik dalam menata jiwa, rasa, pikiran dan perilaku untuk menjalankan kehidupan yang rukun, damai serta harmonis. Untuk mencapai peran tersebut, di butuhkan sosok seorang figur dari guru untuk di jadikan contoh bagi santri dalam melaksanakan shalat berjamaah. Hal ini tetntunya akan memberikan dampak yang positif, baik dalam hal kedisiplinan ataupun penyadaran santri dalam melaksanakan shalat berjamaah. Sehingga ketika santri mendengar suara adzan maka akan dengan penuh kesadaran pergi ke masjid untuk melakukan shalat berjamaah tanpa ada paksaan dari siapapun. 


\section{Daftar Pustaka}

Aziz Fahrurrozi, 2010. Fiqih Manajerial. Jakarta: Al-Mawardi Agus Abdul Rahman, 2013. Psikologi Sosial. Jakarta: Rajawali Pers.

Al-Imam Al-Jalil Al-Hafidz, Imaduddin, Abil Fida Ismail Ibnu Katsir AlQursyiyyi Al Dimasqy, Tafsir Ibnu Katsir, (Semarang: Toha Putra), Jil.3

Ary Ginanjar, 2009. ESQ Power. Jakarta: Arga Publishing

Abudin Nata, 2000. Metodologi Studi Islam. Jakarta: Raja Grafindo Persada

Eman Sulaiman, 2002. Simbol-simbol Salat. Bandung: Madani Prima. Himpunan Undang-undang Sisdiknas dan Sertifikasi Guru.

Ibnu Atha'illah al-Iskandari. Al-Hikam. Jakarta: Turos Khazanah Pustaka Islam

Lajnah Pentashihan Mushaf Al-Qur'an, 2014. Tafsir Al-Qur'an Tematik. Jakarta: Kamil Pustaka

Nana Syaodih, 2005. Metode Penelitian Pendidikan. Bandung: PT Remaja Rosda Karya

Nurcholis Madjid, 1997. Bilik-bilik Pesantren Sebuah Potret Perjalanan, Jakarta: Paramadina

Samir Abdul Halim, Ensiklopedia Sains Islami " Sosiologi”. Tangerang: PT. Kamil Pustaka

Sulaiman Rasjid, 2002. Fiqih Islam. Bandung: Sinar Baru.

Sugiono, 2009. Metode Penelitian Kuantitatif, Kualitatif dan $R \& D$. Bandung: Alfabeta 